\title{
Discussion on Methods for Training Professional Practice Ability of Cross-border E-commerce Talents
}

\author{
Qiang Wu \\ Haikou College of Economics, Haikou Hainan, 571127, China
}

Keywords: cross-border e-commerce; professional practice ability; problems; training methods

\begin{abstract}
With the coming of Internet era, the foreign trade industry has developed rapidly, in which, the cross-border e-commerce has become a new power for the transformation development of some industries, so that the society needs more professional talents. In order to improve the comprehensive level of talent training effectively, the practical teaching shall be taken as a fundamental method, and the integrity of the teaching system and the effectiveness of the supervision and management of talents shall be improved. In this paper, the specific training requirements for the professional practice ability of cross-border e-commerce talents are analyzed briefly, and the existing problems and main training methods are discussed for reference.
\end{abstract}

\section{Specific training requirements for professional practice ability of cross-border e-commerce talents}

In the process of comprehensive analysis and deep understanding of the training of the professional practice ability for the cross-border e-commerce talents, we shall analyze the concrete problems concretely according to the actual situations, and strengthen the talent management and quality control, to guarantee the professional level is improved effectively.

First of all, the cross-border e-commerce talents shall have some business English application ability, so that they can be proficient in the application of English for business negotiations, describe the products correctly, and complete the cross-cultural business communication. Besides, at the same time of trade exchanges, they can effectively analyze the related reports on the English websites, so as to get relevant trade information and carry out the practical work better.

Secondly, the cross-border e-commerce talents shall have the ability of e-commerce application. In the business system of e-commerce, besides the business negotiations, they have to deal with the goods, popularize and manage the shops, and realize the online transaction and distribution management effectively while release the relevant information. Related personnel shall have a clear cognition of the process and basic work, and shall improve their management level and comprehensive quality.

Thirdly, the cross-border e-commerce talents shall have the operational ability and the level of international trade, especially the network operations management of online trade platforms, such as B2B and B2C. In addition, they shall be able to develop customers effectively in virtue of corresponding search engines, integrate the large data techniques to push more relevant information to customers, and complete the operation of foreign trade finally ${ }^{[1]}$.

Finally, the cross-border e-commerce talents shall have the network marketing ability, select corresponding purchasing goods according to the market requirement, analyze the customers' actual demands, effectively carry out relevant overseas retail markets, and deeply integrate the concrete problems through the investigation and analysis, and deal with the trade activities.

\section{Existing problems in training professional practice ability of cross-border e-commerce talents}

Most of the cross border e-commerce talents' initial jobs are provided by the middle and small-sized enterprises. In the employment principles of middle and small-sized enterprises, they 
usually pay more attention to the speed that the employees are familiar with the business, the employees are required to be familiar with all business when they just on duty, and even some of them are required to hold several posts simultaneously, which needs the strict requirements for the professional practical level, occupational level and composite type of cross-border e-commerce talents. However, most of the students of the cross-border e-commerce major still have some shortcomings in the training of practical ability.

\subsection{Lack of professional orientation}

In the process of training the professional practice ability for the cross-border e-commerce talents, the professional orientation is critical. If the orientation is deviated, the talents' social adaptability will be affected greatly. However, in the reform and development of teachers' practice, it is a long way to go for the actual specifications of professional orientation and talent training. Although the cross-border e-commerce trade develops rapidly, the training of the professional practice ability for most of the cross-border talents is not synchronous. Even if the cross-border management has been added, the actual teaching effect and the teaching process are still lagging, and students cannot understand the cross-border trade deeply, which makes the professional structure and orientation of the professional talents are deviated and the practice goal is not clear.

\subsection{Lack of teaching system}

In the process of training the professional practice ability for the cross-border e-commerce talents, because the training of professional practice and the ability training system don't meet the enterprises' needs, the teaching system for talent management is deviated. For the cross-border e-commerce talents, the training of practical ability is crucial, and the proportion of practice courses shall account for over 50\%. However, while organizing the courses, most of the teachers still splice the practice courses and the teaching materials, practical training software, teaching video and other items, which results in that students only watch some materials with insufficient practicality and timeliness in the practice courses. It is this old teaching mechanism and teaching method that lead to the fact that the students' comprehensive ability is not improved effectively. In addition, there are some problems in some practice links of the college teaching, such as the incomplete professional cognition practice and course practice. For example, when arranging the correlated courses, teachers get in contact with the students and conduct the practice and post orientation guidance for students only by network, and there is no process supervision. It is because of this random teaching supervision mechanism that some of the students with less consciousness cannot make progress effectively in the practice process $^{[2]}$.

\subsection{Lack of college-enterprise cooperation system}

For the training of professional practice ability for the cross-border e-commerce talents, in addition to restraining the students' learning behaviors, the teachers shall maintain the practical training environment actively to provide the students with a more effective practical training environment that can improve their comprehensive quality. Therefore, the training base is a key carrier and platform for training practical ability. In the establishment of the training base, the college needs the teachers to guide the students in theory, the enterprise personnel and the technical management department shall carry out the practical guidance to the students, thus forming a resource sharing and management structure. However, the reality is not the case. The staff in most of the enterprises is too busy to attend to the students, and the training courses are often superficial, because they are unwilling to reveal the customer information. It is worth mentioning that in the practical training process, the college needs to take into account the students' accommodation, safety and some other problems, and this process is complicated, which results in that the extramural practice teaching lags behind and cannot be developed and implemented deeply, most of the students in the college-enterprise cooperation become the "free" workers, and the training of the professional practice ability for the cross-border e-commerce talents loses the effectiveness. 


\section{Methods for training professional practice ability of cross-border e-commerce talents}

In order to improve the professional practice ability of the cross-border e-commerce talents effectively, teachers shall actively implement the systematized teaching mechanism, effectively integrate the teaching resources, implement the systematized teaching strategies, maintain the integrity and practical value of the teaching framework from the practical ability and the comprehensive practice level, and actively increase the integrating degree between the teaching training and the practice, thus maintaining the true value of the professional practice teaching for the cross-border e-commerce talents ${ }^{[3]}$.

\subsection{Optimize teaching orientation}

In order to overall improve the training effect of the professional practice ability for the cross-border e-commerce talents, we shall actively implement the precise management and control measures for the course orientation, integrate the market resources and the running states in the background of the development of cross-border e-commerce trade, and ensure the integrity and effectiveness of the education and teaching objectives at the same time of precise orientation, guarantee the orientation management level, make corresponding teaching plans and teaching processes according to the objectives, maintain the system and implementation degree of the teaching framework, effectively control the distribution of relevant resources and information in the orientation system, and ensure that the training direction and practical level of the cross-border e-commerce talents are more in line with the practical needs. Moreover, in the talent training process, with the principle of taking the market as the center, taking the talent supervision and management as the fundamental, and taking the full employment of the students as the basic direction, we shall improve the investigation level and the effect of the tracking investigation for the students, judge the leading-edge information on the education and market effectively, and analyze the talents' actual needs comprehensively. Only by judging and analyzing the development trend of the professional practice teaching for the cross-border e-business talents and the market structure fundamentally can we make the practical and effective management measures and achieve the teaching objectives, thus truly improving the professional practice level of the cross-border e-commerce talents.

\subsection{Optimize teaching system}

For the training of the professional practice ability for the cross-border e-commerce talents, the perfection degree of the teaching system is crucial, which is the basis for determining the students' comprehensive level and basic quality. Only by actively implementing the systematized management and control measures for teaching can we provide guarantee for the subsequent teaching and achieve the teaching objectives for the cross-border e-commerce talents.

First of all, integrate the modular teaching system. In accordance with the basic process of the cross-border trade, teachers shall carry out the operation teaching to students to improve their sense of participation in the class, thus effectively integrating the training level of students' comprehensive ability. In the social demand for the cross-border e-commerce talents, students shall master the business English, e-commerce knowledge, international trade, marketing strategy and other knowledge systems. Teachers shall carry out the corresponding teaching for different teaching modules so as to guarantee to optimize and improve the students' comprehensive ability. 1) Business English teaching module. Teachers shall improve students' comprehensive English level through some tests and training such as online English trading and product description, guide students to read the information on English websites, and obtain relevant information to maintain the customers and ensure the smooth cross-cultural communication. Only really integrating into the culture of other countries can students establish more effective management and control ways for trade exchange. 2) International trade module. Teachers shall guide students to develop new customers in virtue of the engines provided by the network platform, so as to deal with the trade business. When instructing the students, teachers can use some typical cases for the teaching, or invite some students who have graduated to work for the practical education. 3) E-commerce module. In the actual teaching process, 
teachers shall guide the students to use some professional software for later processing, which is fresh and interesting, so teachers can use this course to improve the students' enthusiasm and interest in learning and provide a guarantee for the later teaching ${ }^{[4]}$. 4) Marketing module. For the training of the professional practice ability for the cross-border e-commerce talents, the training of marketing ability is the most critical. Therefore, teachers shall combine the theoretical teaching with the practical teaching, so as to investigate the market effectively, and explore the practical significance of the network marketing system deeply, so as to ensure the integrity of the teaching content and teaching framework.

Secondly, implement the staged teaching system. In the training course for the professional practice ability of the cross-border e-commerce talents, teachers shall implement the progressive teaching measures and effectively play the guiding role of teaching. At the first stage, teachers shall improve the students' cognitive ability to ensure that the students cognize the posts of cross-border trade and understand the basic requirements of the course and learning. Moreover, while explaining some professional practice software, teachers shall stimulate students' interest and enthusiasm in learning, so as to lay a solid foundation for the later teaching. Tutors can take advantage of more innovative assessment methods to give full play to students' subjective initiative in the assessment of this stage. At the second stage, teacher shall make use of some project courses and real practical training modes to formally carry out the training of post skills, in which, the practical training module of network marketing, the practical training module of network trade and the operations management module of cross-border e-commerce are the effective teaching management and control systems, which can guarantee that the students can fully understand the content of the professional practice for the cross-border e-commerce talents. It is important to note that teachers can improve students' participation degree by the enterprise management simulation with Sand Table for the comprehensive practical training, and guarantee the integrity of the teaching framework and the optimization degree of the teaching level. At the third stage, teachers can guide the students to have a deeper understanding of the cross-border e-commerce with occupational experience teaching and provide a teaching system of fixed post practice, to effectively strengthen the students' sense of teamwork and project operation level and stimulate students' creativity, thus truly realizing the training objective of professional practice ability for the cross-border e-commerce talents ${ }^{[5]}$.

\subsection{Optimize practical training base}

In the professional work system, the practical training base is very critical. Therefore, the cross-border e-commerce major shall be linked with some well-known enterprises, the enterprises provide the third-party platform for the courses, the college provides the place for the enterprises, and both parties can organize teachers and managers to establish corresponding sales teams. In this way, not only the students' practice is solved, but also the more creative opportunities for the development of the industry are provided, so as to gain economic profits and achieve win-win college-enterprise cooperation. Compared with traditional store management, the planning and marketing promotion with online technology also can improve the students' comprehensive practical ability effectively.

\section{Conclusion}

In a word, in the training of the professional practice ability of cross-border e-commerce talents, the school shall actively implement the talent management mechanism, ensure the integrity of the management and construction of practical training and the teaching team while perfecting the practice teaching system, and meet the trend of economic change, which will improve the training effect of the professional practice ability for the cross border e-commerce talents to a certain extent, and supply more professional talents to the society.

\section{Acknowledgement}

Educational reform research and scientific research project of higher education of Hainan 
Province: research on training of cross-border e-commerce talents adapting to economic development of Hainan, S/N: Hnjg2016-58.

\section{References}

[1] Xiao Cui, Research on Methods for Training Professional Practice Ability of Cross-border E-commerce Talents, Digital User, 2017(42): 42

[2] Feng Xuehong, Lei Yan, Brief Discussion on Training of Cross-border E-commerce Talents of Business English Major in Educational Background of "Internet Plus" , Chizi, 2017(28): 86-87

[3] Shuai Xiaohua, Analysis of Course Reform and Practice of E-Commerce Logistics in Background of Cross-border E-commerce, Science \& Technology Information, 2017, 27): 169,171

[4] Wu Junli, Research on Training Path of Professional Practice Ability of Inter-disciplinary Cross-border E-commerce and Trade Talents, China Journal of Commerce, 2016(20): 181-182

[5] Yin Huihui, Practice and Thought on Innovation and Entrepreneurship Education for Cross-border E-commerce in International Trade Major of Higher Vocational Colleges, Journal of Guangzhou City Polytechnic, 2016 (02): 31-34. 